\title{
Maintenance of sinus rhythm after DC reversion of atrial fibrillation $A$ double-blind controlled trial of long-acting quinidine bisulphate
}

\author{
Edward Byrne-Quinn ${ }^{1}$ and A. J. Wing ${ }^{2}$ \\ From the Cardiac Department, St. Thomas' Hospital, London S.E. I
}

\begin{abstract}
Ninety-two patients were entered in a double-blind controlled trial of long-acting quinidine bisulphate for the maintenance of sinus rhythm following DC reversion of atrial fibrillation. By random selection two statistically comparable groups of patients were obtained, a control group being given a placebo and a treated group quinidine bisulphate $1.5 \mathrm{~g}$. per day in two 12-hourly doses. Thirty-seven patients were followed up in the control group and twenty-eight patients in the treated group. The maintenance of sinus rhythm in the treated group was significantly longer than in the control group, especially during the first three months. The mean serum quinidine level in the treated group was $2.2 \pm 0.3$ (SEM) mg. per litre. There was one death among the patients treated with quinidine, which may have been due to quinidine toxicity caused by a high serum quinidine level.
\end{abstract}

Sinus rhythm is more efficient haemodynamically and as a rate regulator than atrial fibrillation. In addition, patients reverted to sinus rhythm are relieved of palpitations and are less liable to suffer embolic episodes (Lown, 1967). Reversion of atrial fibrillation to sinus rhythm became simple and safe when DC countershock superseded drug reversion (Lown, Amarasingham, and Neuman, 1962). The main problem now is the maintenance of sinus rhythm after the procedure.

There is controversy about the value and potential danger of using quinidine for maintenance therapy. Some authors state that it should be used prophylactically before DC reversion of arrhythmias and afterwards to maintain sinus rhythm (Lown et al., 1963; Hurst et al., 1964; Korsgren et al., 1965; Morris, Peter, and McIntosh, 1966; Rossi and Lown, 1967; Lown, 1967), while others have considered that it does not prolong the duration of sinus rhythm (Chevalier, 1966; Halmos, 1966; Szekely, Batson, and Stark, 1966; Hall and Wood, 1968). The dangers of quinidine are well documented (Thomson, 1956; Received 2 October 1969.

1 Present address: Cardiovascular Pulmonary Research Laboratory, University of Colorado Medical Center, 4200 East Ninth Avenue, Denver, Colorado 80220, U.S.A.

${ }^{2}$ Requests for reprints should be addressed to A.J.W. at St. Thomas' Hospital.
Oram and Davies, 1964; Davies, Leak, and Oram, 1965; Radford and Evans, 1968).

In this paper we report the results of a double-blind controlled trial of a long-acting preparation of quinidine bisulphate (Kinidin Durules) for the maintenance of sinus rhythm after DC reversion of atrial fibrillation. This preparation produces a slow and prolonged release of quinidine bisulphate. The high peak in blood concentration that occurs after quinidine sulphate is replaced by a plateau which develops gradually and is maintained over 12 hours (Cramér, Varnauskas, and Werkö, 1963; Siitonen, 1964).

\section{Patients and Methods}

Ninety-two patients who had atrial fibrillation and were admitted to hospital between March 1966 and September 1967 for DC reversion were included in the trial. They were randomly allocated to two groups-A and B. An identical tablet was provided for each group. Group A tablet contained placebo, and Group B 0.25 g. quinidine bisulphate in a sustained-release form (Kinidin Durules). This amount of quinidine bisulphate is equivalent to $0.2 \mathrm{~g}$. quinidine sulphate. Henceforth these two groups will be called Group A (control) and Group B (quinidine). The patients were told the nature of the trial but neither they nor the authors knew which tablet contained quinidine bisulphate.

Patients were admitted to hospital for two nights. Digoxin was stopped at least 24 hours before admission. A test dose of quinidine sul- 
phate $200 \mathrm{mg}$. was given to all patients. After allocation to Group A or B, patients were given three of their tablets 4-12 hours before reversion. In Group B (quinidine) this corresponded to a dose of $0.75 \mathrm{~g}$. quinidine bisulphate (equivalent to $0.6 \mathrm{~g}$. quinidine sulphate).

Synchronized DC reversion was performed by the technique described by Lown (1964), using either a Lown (American Optical Company) or a Cardiac Recorders defibrillator. Light general anaesthesia without premedication was given to all patients. Reversion was recorded as successful if the patient left the operating theatre in sinus rhythm. Anticoagulants were given only to those patients who had had embolic phenomena or had Starr-Edwards prosthetic valves; there were 9 such patients in Group $A$ (control) and 5 in Group B (quinidine). An electrocardiogram (standard lead II) was taken before and after reversion and at each follow-up attendance. The electrocardiograms were numbered, stored, and examined separately for rhythm by an independent observer at the end of the trial. Maintenance tablets were started after reversion and patients were instructed to take three tablets at Io a.m. and ro p.m. In Group B (quinidine) this corresponded to a dose of $1.5 \mathrm{~g}$. quinidine bisulphate per day equivalent to $I \cdot 2 \mathrm{~g}$. quinidine sulphate per day.

Patients were withdrawn from the trial and not included in the final analysis if spontaneous reversion to sinus rhythm occurred before DC reversion, if $\mathrm{DC}$ reversion failed to establish sinus rhythm, if there was any evidence clinically or on the electrocardiogram of quinidine toxicity, or if the patient was lost to follow-up.

Patients who were successfully reverted to sinus rhythm were examined at intervals of I day, I week, 2 months, 6 months and, thereafter at 6monthly intervals. In addition, they and their general practitioners were asked to report immediately if relapse to atrial fibrillation occurred. Digoxin was not usually given and only one patient had to be admitted in relapse because of rapid atrial fibrillation. At the end of the trial the maintenance of sinus rhythm in both groups was computed by the life-table or actuarial method (Ederer, I960).

Serum quinidine Blood for serum quinidine estimation was taken at the time of DC reversion and at each follow-up attendance. The serum was refrigerated and stored and the serum quinidine levels measured at the end of the trial by one of us (E. B-Q.). The method used was that of Brodie et al. (1947) as modified by Cramér and Isaksson (1963), and consisted of a double extraction with benzene and sulphuric acid and fluorimetric estimation of quinidine using an AmincoBowman spectrophotofluorimeter. This is the only method that measures quinidine alone, eliminating quinidine metabolites.

\section{Results}

Distribution (Tables I and 2) The distribution of patients between Group A (control)
TABLE I Distribution of patients in each group according to numbers, age, sex, and duration of atrial fibrillation

\begin{tabular}{|c|c|c|c|c|c|c|c|}
\hline \multirow[t]{2}{*}{ Group } & \multirow[t]{2}{*}{$\begin{array}{l}\text { No. } \\
\text { entered }\end{array}$} & \multicolumn{2}{|c|}{$A g e(y r)}$. & \multicolumn{2}{|l|}{ Sex } & \multicolumn{2}{|c|}{$\begin{array}{l}\text { Duration of atrial } \\
\text { fibrillation }(y r .)\end{array}$} \\
\hline & & Mean & Range & $M$ & $F$ & Average & Range \\
\hline $\begin{array}{l}\text { A (control) } \\
\text { B (quinidine) } \\
\text { A plus B }\end{array}$ & $\begin{array}{l}47 \\
45 \\
92\end{array}$ & $\begin{array}{l}54 \\
54 \\
54\end{array}$ & $\begin{array}{l}30-70 \\
37-66 \\
30-70\end{array}$ & $\begin{array}{l}23(49 \%) \\
26(58 \%) \\
49(53 \%)\end{array}$ & $\begin{array}{l}24(51 \%) \\
19(42 \%) \\
43(47 \%)\end{array}$ & $\begin{array}{l}I-2 \\
I-2 \\
I-2\end{array}$ & $\begin{array}{l}\text { I/I2-IO } \\
\text { I/I2-IO } \\
I / 12-10\end{array}$ \\
\hline
\end{tabular}

The distribution between groups is not significantly different.

TABLE 2 Distribution of patients according to aetiology

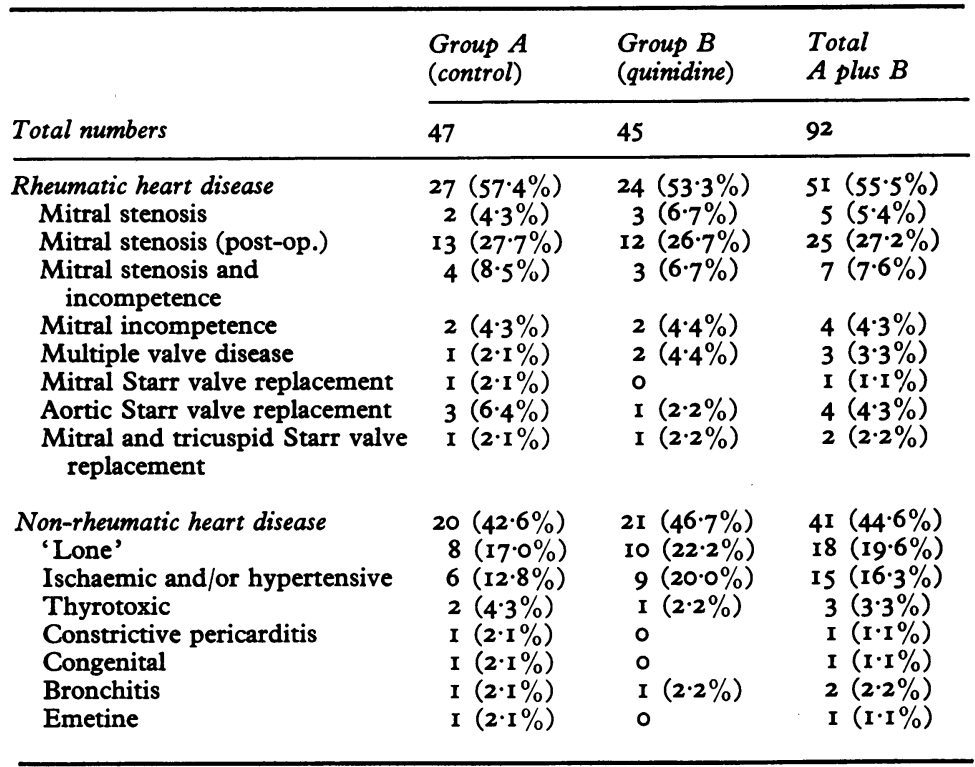

The distribution between the groups and between the totals of rheumatic and nonrheumatic heart disease is not significantly different.

and Group B (quinidine) according to age, sex, duration of atrial fibrillation (Table I), and aetiology (Table 2) is not significantly different by the $\chi^{2}$ test. The total number of patients entered in the trial was 92, of whom 47 were allocated to Group A (control) and 45 to Group B (quinidine).

Withdrawals (Table 3) In Group A (control) Io patients were withdrawn, whereas in Group B (quinidine) 17 patients were withdrawn. This difference is mainly due to the fact that 5 patients in Group B (quinidine) spontaneously reverted to sinus rhythm before DC reversion and were thus withdrawn, whereas there were no spontaneous reversions in Group A (control). In addition, DC reversion was unsuccessful in 5 patients in Group A (control) and in 8 patients in Group B 
(quinidine). The average duration of atrial fibrillation in these failures was between 5 and 10 years in Group A (control) and between 2 and 3 years in Group B (quinidine), which is longer than the averages for the whole groups. Two patients in each group had evidence of quinidine toxicity, two in each group were lost to follow-up, and one patient in Group A (control) was observed to be having bouts of paroxysmal atrial fibrillation on follow-up.

Complications There were no serious complications attributable to the procedure of DC reversion. Arrhythmias occurring after DC reversion and lasting more than 5 minutes occurred in 7 patients in Group A (control) and in 4 patients in Group B (quinidine). During spontaneous reversion to sinus rhythm after one dose of quinidine bisulphate ( $0.75 \mathrm{~g}$.) one patient appeared to have a transient cardiac arrest and was resuscitated by one blow on the chest by a nurse. There was no electrocardiographic recording, and the serum quinidine was not measured. Two patients in Group A (control) had first degree heart block, the PR intervals being 0.28 and 0.50 sec., respectively. In Group B (quinidine) only one patient stopped the drug because of diarrhoea due to the drug. However, in this group there was one patient who died suddenly at home seven days after DC reversion. She was aged 65 and had hypertension and ischaemic heart disease and had been in atrial fibrillation for between one and six months. At the end of the trial it was found that the serum quinidine level had been $4.3 \mathrm{mg}$./litre when DC reversion was performed. At this time the patient had received a test dose of $0.20 \mathrm{~g}$. quinidine sulphate and one dose of $0.75 \mathrm{~g}$. quinidine bisulphate. After reversion she had ventricular bigeminy lasting more than five minutes which had ceased later in the same day. The necropsy was performed elsewhere and showed coronary artery occlusion by atheroma, left ventricular hypertrophy, and patchy left ventricular mural fibrosis. This was the only patient to die in either group.

There was one probable embolic episode. This occurred in a patient in Group A (control) who, five days after DC reversion, relapsed back to atrial fibrillation, and at the same time almost certainly suffered a left renal embolus. She had hypertension and had had a right nephrectomy in the past for pyelonephritis. This patient was not on anticoagulants and made a satisfactory recovery.

In Table 3 it is shown that 37 patients in Group A (control) and 28 in Group B (quini-
TABLE 3 Number of patients entered in each group and withdrawn

\begin{tabular}{|c|c|c|c|}
\hline & $\begin{array}{l}\text { Group A } \\
\text { (control) }\end{array}$ & $\begin{array}{l}\text { Group B } \\
\text { (quinidine) }\end{array}$ & $A+B$ \\
\hline Patients entered & 47 & 45 & 92 \\
\hline \multicolumn{4}{|l|}{ Withdrawn from trial: } \\
\hline $\begin{array}{l}\text { Spontaneous reversion to sinus } \\
\text { rhythm }\end{array}$ & $\circ$ & $5(11 \cdot 1 \%)$ & 5 \\
\hline Failed DC reversion & $5(10.6 \%)$ & $8(20 \cdot 0 \%)$ & $13(14.9 \%)$ \\
\hline Possible quinidine toxicity & 2 & $2 \dagger$ & 4 \\
\hline Lost to follow-up & 2 & 2 & 4 \\
\hline Paroxysmal atrial fibrillation & I & 0 & I \\
\hline Total number withdrawn & I0 & 17 & 27 \\
\hline Patients followed up 5-15 months & 37 & 28 & 65 \\
\hline $\begin{array}{l}\text { Number relapsing to atrial } \\
\text { fibrillation }\end{array}$ & $28(75 \cdot 7 \%)$ & $12(42 \cdot 9 \%)$ & - \\
\hline $\begin{array}{l}\text { Number remaining in sinus } \\
\text { rhythm }\end{array}$ & $9(24 \cdot 3 \%)$ & $16(57 \cdot 1 \%)$ & 一 \\
\hline
\end{tabular}

* The results are here expressed as the number and percentage of those patients followed up for 5-15 months who either relapsed to atrial fibrillation or remained in sinus rhythm.

† Includes one death.

dine) were followed up for periods ranging from 5 to 15 months. In Group A (control) the over-all number of relapses was 28 $(75.7 \%)$; in Group B (quinidine) it was 12 $(42.9 \%)$. Thus 9 patients $(24.3 \%)$ remained in sinus rhythm in Group A (control) and 16 ( $57.1 \%)$ in Group B (quinidine).

The results as expressed in Table 3 do not indicate the duration of sinus rhythm in each group. This is achieved by computing the result by the life-table, or actuarial method given in Table 4. From this it can be seen that the majority of relapses to atrial fibrillation occurred during the first three months: 24 $(65 \%)$ in Group A (control) and $9(32 \%)$ in Group B (quinidine). The cumulative proportion of those patients who remained in sinus rhythm from the time of DC reversion to the end of a given interval is given in column 8. The Fig. is obtained by converting the figures in column 8 to percentages and plotting these against time. This shows graphically the considerable difference in the maintenance of sinus rhythm between the two groups in favour of Group B (quinidine).

Rheumatic and non-rheumatic heart disease. The distribution of patients with rheumatic and non-rheumatic heart disease between the groups was not significantly different in the total number of 92 entered (Table 2). Table 5 shows that this remained so in the 65 patients followed up. In addition, this Table shows that the number in each 
TABLE 4 Computation of maintenance of sinus rhythm by life-table, or actuarial method

\begin{tabular}{|c|c|c|c|c|c|c|c|c|c|c|c|c|c|c|}
\hline \multirow[t]{2}{*}{$\begin{array}{l}\text { (I) } \\
\text { Months after } \\
\text { DC reversion } \\
\text { to sinus } \\
\text { rhythm }\end{array}$} & \multicolumn{2}{|c|}{$\begin{array}{l}\text { (2) } \\
\text { In sinus rhythm } \\
\text { at beginning of } \\
\text { interval }\end{array}$} & \multicolumn{2}{|c|}{$\begin{array}{l}\text { (3) } \\
\text { Relapsed to } \\
\text { atrial fibrillation } \\
\text { during interval }\end{array}$} & \multicolumn{2}{|c|}{$\begin{array}{l}\text { (4) } \\
\text { Withdrawn in } \\
\text { sinus rhythm } \\
\text { during interval }\end{array}$} & \multicolumn{2}{|c|}{$\begin{array}{l}\text { (5) } \\
\text { Effective no. } \\
\text { exposed to risk } \\
\text { or relapsing to } \\
\text { atrial fibrillation } \\
\left.\text { (col. } 2-\frac{1}{2} \text { col. } 4\right)\end{array}$} & \multicolumn{2}{|c|}{$\begin{array}{l}(6) \\
\text { Proportion re- } \\
\text { lapsing to atrial } \\
\text { fibrillation } \\
\text { (col. } 3 / \mathrm{col} .5)\end{array}$} & \multicolumn{2}{|c|}{$\begin{array}{l}\text { (7) } \\
\text { Proportion re- } \\
\text { maining in sinus } \\
\text { rhythm } \\
(I-\text { col. 6) }\end{array}$} & \multicolumn{2}{|c|}{$\begin{array}{l}\text { ( }) \text { (umulative propor- } \\
\text { tion remaining in } \\
\text { sinus rhythm from } \\
\text { DC reversion to end } \\
\text { of interval, } \pm S E M\end{array}$} \\
\hline & $\begin{array}{l}A \\
(\text { con- } \\
\text { trol })\end{array}$ & $\begin{array}{l}B \\
\text { (quini- } \\
\text { dine) }\end{array}$ & $\begin{array}{l}A \\
(\text { con- } \\
\text { trol })\end{array}$ & $\begin{array}{l}B \\
\text { (quini- } \\
\text { dine) }\end{array}$ & $\begin{array}{l}\text { A } \\
(\text { con- } \\
\text { trol })\end{array}$ & $\begin{array}{l}B \\
\text { (quini- } \\
\text { dine) }\end{array}$ & $\begin{array}{l}\text { A } \\
(\text { con- } \\
\text { trol })\end{array}$ & $\begin{array}{l}\text { B } \\
\text { (quini- } \\
\text { dine) }\end{array}$ & $\begin{array}{l}A \\
(\text { con- } \\
\text { trol })\end{array}$ & $\begin{array}{l}\text { B } \\
\text { (quini- } \\
\text { dine) }\end{array}$ & $\begin{array}{l}\text { A } \\
\text { (con- } \\
\text { trol) }\end{array}$ & $\begin{array}{l}\text { B } \\
\text { (quini- } \\
\text { dine) }\end{array}$ & $\begin{array}{l}A \\
\text { (con- } \\
\text { trol })\end{array}$ & $\begin{array}{l}B \\
\text { (quini- } \\
\text { dine) }\end{array}$ \\
\hline $0-3$ & 37 & 28 & 24 & 9 & 0 & 0 & 37 & 28 & 0.65 & 0.32 & 0.35 & 0.68 & $\begin{array}{r}0.35 \\
\pm 0.08\end{array}$ & $\begin{aligned} & 0.68^{\star} \\
\pm & 0.09\end{aligned}$ \\
\hline $3-6$ & 13 & 19 & I & 0 & I & 2 & 12.5 & 18 & 0.08 & 0 & 0.92 & $\mathbf{I}$ & $\begin{array}{r}0.32 \\
\pm 0.08\end{array}$ & $\begin{array}{r}0.68 * \\
\pm 0.09\end{array}$ \\
\hline $6-9$ & II & 17 & $\mathbf{I}$ & 0 & 5 & 4 & $8 \cdot 5$ & 15 & 0.12 & 0 & 0.88 & $\mathbf{I}$ & $\begin{array}{r}0.29 \\
+0.08\end{array}$ & $\begin{aligned} & 0.68^{\star} \\
\pm & 0.09\end{aligned}$ \\
\hline $9-12$ & 5 & I I & 2 & 2 & I & 2 & 4.5 & IO & 0.44 & 0.20 & 0.56 & 0.80 & $\begin{array}{r}0.16 \\
+0.08\end{array}$ & $\begin{array}{r}0.54^{\star} \\
\pm 0.11\end{array}$ \\
\hline $12-15$ & 2 & 8 & 0 & I & 2 & 4 & $\mathbf{I}$ & 6 & 0 & 0.17 & I & 0.83 & $\begin{array}{r}0.16 \\
\pm 0.08\end{array}$ & $\begin{array}{r}0.45^{\star} \\
\pm 0.12\end{array}$ \\
\hline
\end{tabular}

$\star \cdot p<0.01$

group who relapsed to atrial fibrillation in the first three months was not significantly different between rheumatic and non-rheumatic heart disease.

Further analysis of the 65 patients followedup showed that the differences of age, sex, and duration of atrial fibrillation between the groups remained not significant. However, the average duration of previous atrial fibrillation in these patients in both groups was between six months and one year which was less than in the total entered.

There was no sex difference in the three months relapse rate. In Group A (control) there were 14 women and 14 men, and in Group B (quinidine) 4 women and 5 men.

Energy to revert The mean energy to re-

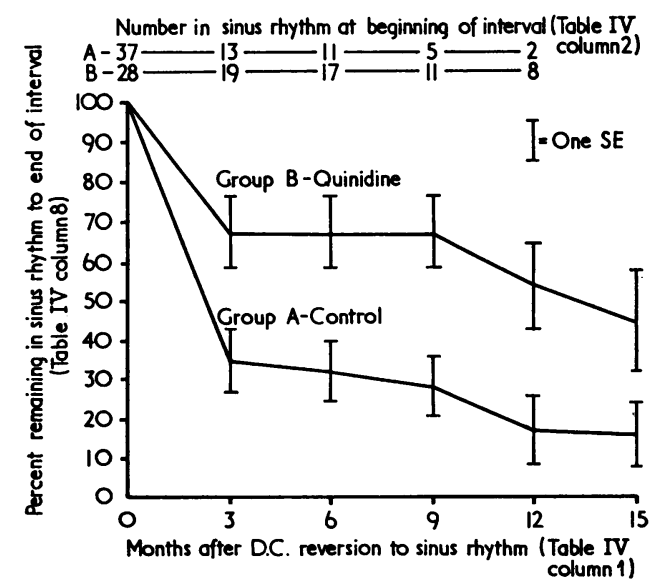

FIG. Maintenance of sinus rhythm in the two groups.
TABLE 5 Rheumatic and non-rheumatic

heart disease: distribution of 65 patients

followed up and numbers relapsing in first

three months

\begin{tabular}{|c|c|c|c|c|c|c|}
\hline \multirow[t]{2}{*}{ Aetiology } & \multicolumn{3}{|c|}{ No. followed up } & \multicolumn{3}{|c|}{$\begin{array}{l}\text { No. relapsing to atrial } \\
\text { fibrillation in first } 3 \text { months }\end{array}$} \\
\hline & $\begin{array}{l}\text { Group A } \\
\text { (control) }\end{array}$ & $\begin{array}{l}\text { Group B } \\
\text { (quinidine) }\end{array}$ & $\begin{array}{l}\text { Total } \\
A+B\end{array}$ & $\begin{array}{l}\text { Group A } \\
\text { (control) }\end{array}$ & $\begin{array}{l}\text { Group B } \\
\text { (quinidine) }\end{array}$ & $\begin{array}{l}\text { Total } \\
A+B\end{array}$ \\
\hline $\begin{array}{l}\text { Rheumatic heart } \\
\text { disease }\end{array}$ & 19 & 14 & 33 & 14 & 4 & 18 \\
\hline $\begin{array}{l}\text { Non-rheumatic heart } \\
\text { disease }\end{array}$ & 18 & 14 & 32 & 10 & 5 & 15 \\
\hline $\begin{array}{l}\text { Total rheumatic and } \\
\text { non-rheumatic }\end{array}$ & 37 & 28 & 65 & 24 & 9 & 33 \\
\hline
\end{tabular}

These figures show no significant difference between rheumatic and non-rheumatic heart disease at the $10 \%$ level.

vert in Group A (control) was $146 \pm 12 \cdot 6$ (SEM) joules and in Group B (quinidine) $128 \pm 12.5$ joules. These differences are not statistically significant.

Serum quinidine The results of serum quinidine estimations in Group B (quinidine) are given in Table 6 . The mean for all estimations was $2 \cdot 2 \pm 0 \cdot 1$ (SEM) mg./litre. There was no significant difference between the serum quinidine levels at the time of reversion and at the time of follow-up, nor between the levels of those patients who relapsed to atrial fibrillation or who remained in sinus rhythm.

\section{Discussion}

By conducting a double-blind controlled trial and by random selection, obtaining two statistically comparable groups, it has been shown 
conclusively that maintenance therapy with a long-acting quinidine bisulphate preparation (Kinidin Durules) prolongs the duration of sinus rhythm after DC reversion of atrial fibrillation.

Various authors have reported that over one-third of cases who relapsed to atrial fibrillation after successful DC reversion to sinus rhythm did so within the first three months (Korsgren et al., 1965; Morris et al., 1966; Hall and Wood, r968). In this series, threequarters of those patients who relapsed in either group did so within the first three months. The fact that 24 out of 37 patients in the control group relapsed during this period whereas only 9 out of 28 patients in the quinidine treated group did so is confirmation that quinidine is advantageous during this critical period (Morris et al., 1964; Reinikainen et al., 1965; Rossi and Lown, 1967).

It has been suggested by some authors that quinidine does not prolong the duration of sinus rhythm (Oram and Davies, 1964; Chevalier, 1966; Halmos, 1966; Szekely et al., 1966; Hall and Wood, 1968). The only other trial has been carried out by Hall and Wood (1968) in 94 patients all of whom had rheumatic heart disease. These investigators divided their patients into two groups on a basis of admission to two different hospitals. Patients at one hospital were given quinidine sulphate I g. per day in divided doses, and patients at the other hospital were given no quinidine. They found exactly the same mean serum quinidine level of $2 \cdot 2 \mathrm{mg}$./litre $(S D \pm I \cdot I)$ as was found in the present study using the same method for estimation. There was no statistically significant difference between the number of cases maintaining sinus rhythm in their treated group and in their control group, expressing the result as percentages of the number of patients successfully reverted and followed for specific time periods as in the Fig. Both their groups had similar maintenance of sinus rhythm as Group B (quinidine) (Fig). In addition to their trial they showed that patients with non-rheumatic heart disease maintained sinus rhythm significantly longer than those in the rheumatic group. We have found no significant difference in the number relapsing during the critical first three months with either aetiology. It is difficult to explain why the control group in the present trial did so badly as compared with theirs. It appears that their patients with rheumatic heart disease fared better without quinidine.

Advocates of quinidine therapy have suggested that relapse to atrial fibrillation after successful reversion to sinus rhythm will
TABLE 6 Comparison of mean serum quinidine levels of patients at time of reversion with those at follow-up, and those who relapsed to atrial fibrillation with those who remained in sinus rhythm

\begin{tabular}{|c|c|c|c|c|c|}
\hline & Total & $\begin{array}{l}\text { At time of } \\
\text { reversion }\end{array}$ & $\begin{array}{l}\text { At follow- } \\
u p\end{array}$ & $\begin{array}{l}\text { Relapsed } \\
\text { to atrial } \\
\text { fibrillation }\end{array}$ & $\begin{array}{l}\text { Remained } \\
\text { in sinus } \\
\text { rhythm }\end{array}$ \\
\hline $\begin{array}{l}\text { No. of samples } \\
\text { Mean serum quinidine } \\
\quad(\mathrm{mg} \text {./litre } \pm \text { SEM })\end{array}$ & $\begin{array}{l}69 \\
2 \cdot 2 \pm 0 \cdot 1\end{array}$ & $\begin{array}{l}15 \\
2 \cdot 0 \pm 0 \cdot 3\end{array}$ & $\begin{array}{l}54 \\
2 \cdot 3 \pm 0 \cdot 1\end{array}$ & $\begin{array}{l}\text { 10 } \\
1 \cdot 9 \pm 0.3\end{array}$ & $\begin{array}{l}53 \\
2 \cdot 2 \pm 0 \cdot 1\end{array}$ \\
\hline
\end{tabular}

The differences are not statistically significant.

occur in 85 per cent of cases if the drug is not used (Goldman, 1960; Sokolow and Perloff, 196I). Because of the differences in presentation of results, length of follow-up, and preparations of quinidine used, it is difficult to compare the results of the treated group in this trial with other series. The same quinidine bisulphate preparation in a dose of $2.0 \mathrm{~g}$. per day has been used by Korsgren et al. (1965) with similar results. Better results were reported by Reinikainen $e t$ al. (1965), with the same drug in doses between 0.8 and $1.2 \mathrm{~g}$./day, and by Hurst et al. (1964) using quinidine sulphate 0.2 g. 6-hourly. Morris et al. (I966) using quinidine gluconate maintained a serum quinidine level of $4.0 \mathrm{mg}$./litre, as measured by the method of Edgar and Sokolow (1950), which gives higher results than the present method. Expressing their results as duration of maintained sinus rhythm in 100 patients they obtained similar results to Group B (quinidine) in the Fig. However one-third of these patients had undergone more than one episode of DC reversion.

Lown (1967) has used quinidine sulphate maintenance therapy ( $0.3 \mathrm{~g}$. every 6 hours), and has reported that of the first roo patients reverted, 23 per cent had remained in sinus rhythm by 1965 . The first patient with atrial fibrillation was treated in $196 \mathrm{I}$. He has stated that 50 per cent of patients subjected to DC reversion remained in sinus rhythm for at least one year.

The energy level used to convert to sinus rhythm was not significantly different between either of the two groups. Therefore, this does not confirm the findings of Rossi and Lown (1967) who required less energy in a group of 25 patients premedicated with quinidine sulphate compared with 25 control patients.

Any advantage in the use of quinidine for the maintenance of sinus rhythm must be balanced against the risks. The occasional occurrence of serious ventricular arrhythmias 
and sudden death is well known (Thomson, 1956; Selzer and Wray, 1964; Davies et al., 1965). Some workers have abandoned the use of quinidine because of these complications (Oram and Davies, 1964; Halmos, 1966; Radford and Evans, 1968). One patient in the present series died and she was in Group B (quinidine): though she had severe ischaemic heart disease the suddenness of her death and the high serum quinidine level of $4.3 \mathrm{mg}$./ litre at the time of $\mathrm{DC}$ reversion suggest that quinidine toxicity was likely.

Serum quinidine was measured retrospectively in this trial. The method chosen is the only method that measures quinidine alone (Brodie et al., 1947; Cramér and Isaksson, I963). Other methods measure quinidine and its metabolites (Brodie and Udenfriend, I943; Newton and Crawford, 1955; Edgar and Sokolow, 1950; Balatre, Lefèvre, and Merlen, 1960). As quinidine metabolites are generally less active as antiarrhythmic agents (Conn, 1964; Conn and Luchi, 1964), it appeared logical to choose the method that measures quinidine alone. Quinidine in small doses and with low blood levels has been shown to produce ventricular arrhythmias (Selzer and Wray, 1964), but Sokolow and Ball (1956) found that myocardial toxicity was infrequent at serum quinidine levels of 6.0 mg./litre by their method (Edgar and Sokolow, 1950). This level is equivalent to 3.5 $\mathrm{mg}$./litre by the method used in this study, and it has been our policy since the trial not to exceed this level.

The patients were under the care of the late Dr. Evan Jones, Dr. Raymond Daley, and Mr. M. V. Brambridge. We wish to thank Professor W. I. Cranston and Professor W. W. Holland for their helpful advice, and Dr. Ch. Fessas, Dr. S. Jenkins, and Dr. D. Pratt for their assistance. Dr. R. R. McSwiney kindly provided laboratory facilities.

The placebo tablets were supplied by AstraHewlett Limited.

\section{References}

Balatre, P. H., Lefèvre, C. L., and Merlen, J. F. (1960). Dosage fluorescimétrique de la quinine et de la quinidine dans le serum sanguin et dans les urines. Annales de Biologie Clinique, 18, 228.

Brodie, B. B., and Udenfriend, S. (1943). The estimation of quinine in human plasma with a note on the estimation of quinidine. Fournal of Pharmacology and Experimental Therapeutics, 78, 154.

,,-- Dill, W., and Downing G. (1947). The estimation of basic organic compounds in biological material. II. Estimation of fluorescent compounds. fournal of Biological Chemistry, 168, 311 .

Chevalier, H. (1966). A plea for atrial fibrillation. American Heart fournal, 72, 423.

Conn, H. L. (1964). Quinidine as an antiarrhythmic agent. Advances in Cardiopulmonary Diseases, 2, 286. $\longrightarrow$, and Luchi, R. J. (1964). Some cellular and metabolic considerations relating to the action of quinidine as a prototype antiarrhythmic agent. American fournal of Medicine, 37, 685 .

Cramér, G., and Isaksson, B. (1963). Quantitative determination of quinidine in plasma. Scandinavian Fournal of Clinical and Laboratory Investigation, 15, 553.

—, Varnauskas, E., and Werkö, L. (1963). A new quinidine preparation with sustained release. Acta Medica Scandinavica, 173, 511 .

Davies, P., Leak, D., and Oram, S. (1965). Quinidineinduced syncope. British Medical fournal, 2, 517.

Ederer, F. (1960). A simple method for determining standard errors of survival rates, with tables. Fournal of Chronic Diseases, $11,632$.

Edgar, A. L., and Sokolow, M. (1950). Experiences with the photofluorimetric determination of quinidine in blood. Fournal of Laboratory and Clinical Medicine, 36, 478.

Goldman, M. J. (1960). The management of chronic atrial fibrillation: indications for and method of conversion to sinus rhythm. Progress in Cardiovascular Disease, 2, 465 .

Hall, J. I., and Wood, D. R. (1968). Factors affecting cardioversion of atrial arrhythmias with special reference to quinidine. British Heart fournal, 30, 84.

Halmos, P. B. (1966). Direct current conversion of atrial fibrillation. British Heart fournal, 28, 302.

Hurst, J. W., Paulk, E. A., Jr., Proctor, H. D., and Schlant, R. C. (I964). Management of patients with atrial fibrillation. American fournal of Medicine, 37, 728.

Korsgren, M., Leskinen, E., Peterhoff, V., Bradley, E., and Varnauskas, E. (1965). Conversion of atrial arrhythmias with D.C. shock. Primary results and a follow-up investigation. Acta Medica Scandinavica, Suppl. 43I.

Lown, B. (1964). 'Cardioversion' of arrhythmias. II. Modern Concepts of Cardiovascular Disease, 33, 869.

- (1967). Electrical reversion of cardiac arrhythmias. British Heart fournal, 29, 469.

—, Amarasingham, R., and Neuman, J. (1962). New method for terminating cardiac arrhythmias. Use of synchronized capacitor discharge. Fournal of the American Medical Association, 182, 548.

- Perlroth, M. G., Kaidbey, S., Abe, T., and Harken, D. E. (1963). 'Cardioversion' of atrial fibrillation. A report on the treatment of 65 episodes in 50 patients. New England fournal of Medicine, 269, 325.

Morris, J. J., Jr., Kong, Y., North, W. C., and McIntosh, H. D. (1964). Experience with 'cardioversion' of atrial fibrillation and flutter. American Fournal of Cardiology, 14, 94.

- Peter, R. H., and McIntosh, H. D. (1966). Electrical conversion of atrial fibrillation. Annals of Internal Medicine, 65, 216.

Newton, G., and Crawford, E. J. (1955). A study of quinidine dosage in infants and children. Fournal of Pediatrics, 47, 700 .

Oram, S., and Davies, J. P. H. (1964). Further experience of electrical conversion of atrial fibrillation to sinus rhythm: analysis of 100 patients. Lancet, $\mathbf{I}$, 1294.

Radford, M. D., and Evans, D. W. (1968). Long-term results of DC reversion of atrial fibrillation. British Heart fournal, 30, 91.

Reinikainen, M., Koskinen, P., Pöntinen, P., and Siitonen, L. (1965). Experiences in the use of direct current countershock in the treatment of cardiac arrhythmias. Acta Medica Scandinavica, Suppl. 437.

Rossi, M., and Lown, B. (1967). The use of quinidine 
in cardioversion. American fournal of Cardiology, 19, 234.

Selzer, A., and Wray, H. W. (1964). Quinidine syncope. Paroxysmal ventricular fibrillation occurring during treatment of chronic atrial arrhythmias. Circulation, 30, 17.

Siitonen, L. (1964). Long-acting quinidine preparations. (Finnish.) Duodecim, 80, 686.

Sokolow, M., and Ball, R. E. (1956). Factors influencing conversion of chronic atrial fibrillation with special reference to serum quinidine concentration. Circulation, 14, 568.

-, and Perloff, D. B. (196I). The clinical pharmacology and use of quinidine in heart disease. Progress in Cardiovascular Disease, 3, 316.

Szekely, P., Batson, G. A., and Stark, D. C. C. (1966). Direct current shock therapy of cardiac arrhythmias. British Heart fournal, 28, 366.

Thomson, G. W. (1956). Quinidine as a cause of sudden death. Circulation, 14, 757. 